
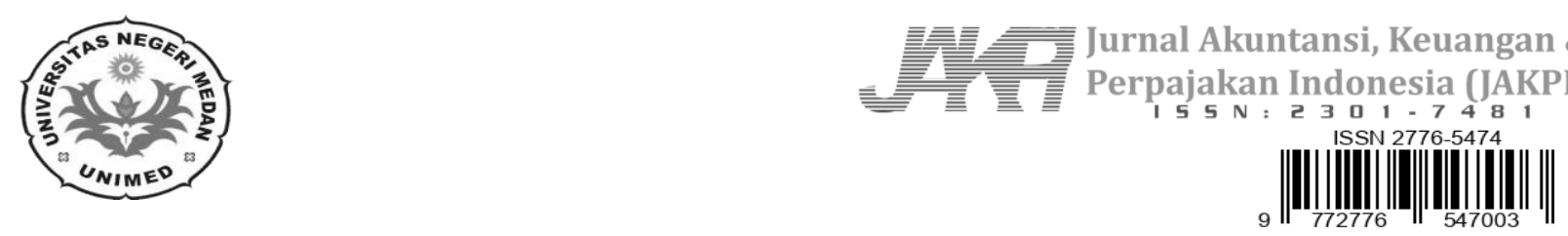

\title{
Pengaruh Pressure Terhadap Perilaku Kecuranganak Ademik Pada Mahasiswa Fakultas Ekonomi Programstudi Pendidikan Akuntansi Universitas Negeri Medan
}

\author{
Maulida Fitri ${ }^{1}$, Ulfa Nurhayani ${ }^{2}$, Choms Gary Ganda Tua Sibarani ${ }^{3}$ \\ Universitas Negeri Medan ${ }^{1}$, Universitas Negeri Medan², Universitas Negeri Medan ${ }^{3}$
}

\begin{abstract}
Abstrak
Masalah dalam penelitian ini adalah banyaknya kecurangan yang terjadi dilingkungan akademik yang dilakukan oleh mahasiswa, dan menganggap hal tersebut merupakan hal yang biasa. Penelitian ini dilaksanakan di Fakultas Ekonomi Program Studi Pendidikan Akuntansi Universitas Negeri Medan. Penelitian ini bertujuan untuk menguji pengaruh pressure, opportunity, dan rationalization terhadap perilaku kecurangan akademik pada mahasiswa program studi pendidikan akuntansi fakultas ekonomi Universitas Negeri Medan. Jenis penelitian ini merupakan penelitian kuantitatif, dengan menggunakan kuesioner sebagai instrumen penelitian yang diukur dengan skala likert. Teknik pemilihan sampel menggunakan purposive sampling. Populasi yang digunakan dalam penelitian ini adalah mahasiswa program studi pendidikan akuntansi fakultas ekonomi Universitas Negeri Medan, jumlah sampel dalam penelitian ini adalah 193 mahasiswa. Teknik analisis data yang digunakan adalah analisis regresi linier berganda dengan menggunakan software IBM SPSS versi 20. Hasil penelitian ini menyatakan bahwa pressure, dan secara parsial berpengaruh positif signifikan terhadap perilaku kecurangan akademik pada mahasiswa program studi pendidikan akuntansi fakultas ekonomi Universitas Negeri Medan. Pressure berpengaruh positif terhadap perilaku kecurangan akademik sebesar 14,2\%.
\end{abstract}

Key Words : pressure, perilaku kecurangan akademik 


\section{Pendahuluan}

Kecurangan akademik (academic fraud) adalah bentuk kecuarangan yang dilakuakan, seperti bekerja sama saat ujian, melihat buku, membawa catatan kecil saat ujian dan browsing handphone, dan menggandakan tugas hasil pekerjaan temannya. Dengan sadar ataupun tidak mahasiswa telah melakukan perbuatan yang mengarah kepada kecurangan akademik (academic fraud).

Teori penelitian ini di ambil dari fraud triangle, yaitu suatu gagasan yang meneliti tentang penyebab terjadinya kecurangan. Gagasan ini pertama kali diciptakan oleh Cressey (1953) diperkenalkan dalam literatur profesional pada SAS No. 99, yang dinamakan fraud triangle (segitiga kecurangan). Fraud triangle menjelaskan tiga faktor yang hadir dalam setiap situasi fraud (1). Pressure (tekanan) yaitu adanya insentif/tekanan/kebutuhan untuk melakukan fraud. Tekanan dapat mencakup hampir semua hal termasuk gaya hidup, tuntutan ekonomi, dan lain-lain termasuk hal keuangan dan non keuangan. Menurut SASNo. 99, terdapat empat jenis kondisi yang umum terjadi pada pressure yang dapat mengakibatkan kecurangan. Yaitu financial stability, external pressure, personal financial need, dan financial targets. (2) Opportunity (peluang), yaitu situasi yang membuka peluang untuk memungkinkan suatu kecurangan terjadi. Diantara elemen fraud diamond yang lain, opportunity merupakan elemen yang paling memungkinkan diminimalisir melalui penerapan proses, prosedur, dan upaya deteksi dini terhadap fraud. (3) Rationalization (rasionalisasi) yaitu adanya sikap, karakter, atau serangkaian nilai-nilai etis yang membolehkan pihak-pihak tertentu untuk melakukan tindakan kecurangan, atau orang-orang yang berada dalam lingkungan yang cukup menekan yang membuat mereka merasionalisasi tindakan fraud.

Menurut Zaini dan Setiawan (2015) "apabila seorang mahasiswa sudah terbiasa melakukan kecurangan (fraud), maka pada saat terjun dalam dunia kerja ada kemungkinan besar seseorang tersebut untuk melakukan kecurangan". Jadi, pendidikan juga mempunyai peranan penting dalam pencegahan tindakan- tindakan kecurangan karena pendidikan merupakan instrumen penting dalam pembangunan bangsa baik sebagai pengembang dan peningkat produktivitas nasional maupun sebagai pembentuk karakter bangsa. Sehubungan dengan hal ini dapat disimpulkan bahwa tujuan Pendidikan Nasional tidak dapat dicapai apabila kecurangan akademik ini masih terjadi karena dapat berpengaruh pada kualitas tenaga kerja maupun pemimpin bangsa yang tercipta di masa yang akan datang. Berikut hasil persentase yang penulis dapatkan mengenai perilaku kecurangan akademik pada mahasiswa Fakultas Ekonomi Program Studi Pendidikan Akuntansi Universitas Negeri Medan melalui angket yang diberikan kepada 372 mahasiswa.

Tabel 1. 1 : Persentase Mahasiswa Fakultas Ekonomi Program Studi Pendidikan Akuntansi Universitas Negeri Medan Angkatan 2016, 2017, 2018 dan 2019 Yang Melakukan Kecurangan Akademik

\begin{tabular}{|c|l|c|c|}
\hline No & \multicolumn{1}{|c|}{ Jenis kecurangan Akademik } & $\begin{array}{c}\text { Jumlah mahasiswa yang } \\
\text { Menjawab Pernah }\end{array}$ & Persentase \\
\hline 1 & $\begin{array}{l}\text { Menyalin jawaban teman pada saat } \\
\text { ujian ataupun pada saat mengerjakan } \\
\text { tugas }\end{array}$ & 345 Mahasiswa & $98,5 \%$ \\
\hline 2 & $\begin{array}{l}\text { Copy paste tugas tanpa mengubahnya } \\
\text { sedikit pun, hanya memperbaiki ukuran } \\
\text { font nya saja }\end{array}$ & 330 Mahasiswa & $94,2 \%$ \\
\hline 3 & Membuat catatan kecil saat ujian & 175 Mahasiswa & $50 \%$ \\
\hline 4 & $\begin{array}{l}\text { Kerjasama dengan teman saat } \\
\text { mengerjakan ujian }\end{array}$ & 340 Mahasiswa & $97,1 \%$ \\
\hline
\end{tabular}

(Sumber: Hasil Angket Pra Penelitian)

Dari 350 mahasiswa yang penulis observasi tersebut mengakui bahwa mereka pernah melakukan kecurangan akademik. Dari hasil yang didapat sebanyak 98,5\% mahasiswa pernah menyalin jawaban teman pada saat ujian, sebanyak 94,2\% mahasiswa yang copy paste tugas tanpa 
mengubahnya sedikit pun, terdapat 50\% mahasiswa yang membuat catatan kecil saat ujian, dan juga terdapat $97,1 \%$ mahasiswa yang melakukan kerjasama saat ujian dengan teman.

Penelitian yang dilakukan oleh Apriani, Sujana, dan Sulindawati (2017), hasil penelitian ini menyatakan bahwa pressure dan rationalization secara parsial berpengaruh signifikan sedangkan opportunity secara parsial tidak berpengaruh signifikan terhadap perilaku kecurangan akademik pada mahasiswa akuntansi. Penelitian ini juga menunjukkan bahwa secara simultan ketiga variabel independen berpengaruh signifikan terhadap perilaku kecurangan akademik pada mahasiswa akuntansi program S1 Universitas Pendidikan Ganesha.

Kemudian penelitian yang dilakukan oleh Pamungkas (2015), hasil penelitian ini menyatakan bahwa pressure dan opportunity secara parsial berpengaruh positif signifikan terhadap perilaku kecurangan akademik. Namun rationalization menunjukkan berpengaruh negatif signifikan terhadap perilaku kecurangan akademik pada mahasiswa Program Studi Akuntansi Fakultas Ekonomi Universitas Islam Indonesia. Berdasarkan latar belakang diatas peneliti tertarik untuk melakukan penelitian tentang "Pengaruh Pressure, Opportunity, dan Rationalization Terhadap Perilaku Kecurangan Akademik Pada Mahasiswa Fakultas Ekonomi Program Studi Pendidikan Akuntansi Universitas Negeri Medan”.

\section{Kerangka Teoritis Dan Pengembangan Hipotesis}

\subsection{Landasan Teori}

\subsubsection{Kecurangan Akademik}

Menurut Oktaviani (2018) kecurangan akademik (academic fraud) merupakan suatu bentuk perilaku yang buruk dan akan memberikan dampak negatif terhadap mahasiswa. Kecurangan akademik yang sering terjadi diantaranya adalah kecurangan yang berupa menyontek saat mengerjakan tugas, menyontek menggunakan catatan kecil/HP, menyalin pekerjaan teman dengan atau tanpa persetujuan, berbohong untuk mendapatkan beasiswa dan lain sebagainya, hal tersebut telah memberikan gambaran mengenai kemerosotan nilai- nilai moral secara umum dan lingkungan masyarakat secara luas.

Menurut Irianto dan Novianti ( 2018 : 23) dealing with fraud :fraud merupakan tindakan yang disengaja (deliberate atau intentional act) atau tindakan yang dilakukan karena ceroboh (reckless), yang dilakukan untuk memperoleh keuntungan secara tidak legal (melanggar hukum), melalui trick tertentu yang pada umumnya tidak dengan kekerasan fisik, dan dilakukan oleh individu, kelompok, atau bahkan organisasi yang memiliki dampak merugikan pihak lain (individu, organisasi, atau negara).

Berdasarkan uraian pendapat diatas dapat disimpulkan pengertian perilaku kecurangan akademik adalah suatu tindakan tidak jujur melanggar etika dalam lingkup akademik.

\subsubsection{Indikator Kecurangan Akademik}

Indikator yang digunakan untuk mengukur variabel kecurangan akademik menurut Zaini dan Setiawan (2015) :

1) Menyalin jawaban tugas milik mahasiswa lain merupakan bentuk kecurangan akademik.

2) Mahasiswa membuat catatan kecil saat ujian merupakan bentuk kecurangan akademik.

3) Memberikan contekan kepada teman saat ujian merupakan bentuk kecurangan akademik.

4) Menitip tanda tangan kehadiran kepada teman merupakan bentuk kecurangan akademik.

5) Menjiplak persis tanpa mencantumkan sumbernya (plagiat) merupakan bentuk kecurangan akademik.

6) Mencari bocoran soal ujian dari teman di kelas lainnya merupakan bentuk kecurangan akademik.

Menurut Colby (2006) yang diutarakan oleh Sagoro (2013) indikator kecurangan akademik yaitu :

1) Menyalin jawaban orang lain ketika ujian.

2) Menggunakan metode tidak jujur untuk mengetahui apa yang akan diujikan.

3) Melakukan kerjasama dengan pengajar. 
4) Menyalin beberapa kalimat (termasuk dari internet) tanpa memasukkan keterangannya ke dalam daftar pustaka.

5) Melakukan tindakan plagiat.

Dari kedua pendapat ahli diatas, penulis menyimpulkan bahwa indikator kecurangan akademik yang digunakan dalam penelitian ini adalah :

a) Menyalin jawaban teman pada saat mengerjakan tugas ataupun pada saat ujian.

b) Membuat catatan kecil saat ujian.

c) Menjiplak persis tanpa mencantumkan sumbernya (plagiat)

d) Menitip tanda tangan kehadiran kepada teman

e) Mencari bocoran soal ujian dari teman di kelas lainnya

\subsubsection{Pressure}

Pressure (tekanan) adalah dorongan atau motivasi seseorang untuk melakukan kecurangan, misalnya karena tekanan karena faktor keuangan, kebiasaan buruk yang dimiliki seseorang, faktor eksternal dan lain-lain.

Menurut Apriani dan Sulindawati (2017) pressure (tekanan) merupakan situasi yang dimana mendorong seseorang melakukan kecurangan. Dorongan tersebut dapat bersumber dari tuntutan gaya hidup, tuntutan orang tua, ekonomi keluarga, dsb. Tekanan yang dimaksud dalam konteks kecurangan akademik merupakan dorongan yang dihadapi mahasiswa dalam mendapatkan hasil akademik sesuai dengan yang diharapkan meskipun menggunakan cara apapun untuk meraihnya, termasuk dalam melakukan tindak kecurangan akademik.

Menurut Prawira dan Irianto (2014) tekanan adalah dorongan atau motivasi yang ingin dicapai tetapi dibatasi oleh ketidakmampuan untuk meraihnya, sehingga dapat mengakibatkan seseorang melakukan kecurangan.

\subsubsection{Indikator Pressure (Tekanan)}

Indikator untuk mengukur variabel pressure (tekanan) menurut Zaini dan Setiawan (2015) :

1) Kurangnya pemahaman terhadap materi perkuliahan .

2) Soal ujian yang sulit.

3) Tuntutan dari orang tua untuk mendapatkan IP yang bagus.

Menurut Prawira (2015) :

1) Menganggap bahwa Indeks Prestasi merupakan hal yang sangat penting.

2) Tidak mempunyai waktu yang cukup untuk menyelesaikan tugas tanpa melakukan kecurangan.

Dari kedua pendapat ahli diatas, penulis menyimpulkan bahwa indikator variabel pressure (tekanan) yang digunakan dalam penelitian ini adalah :

a) Tuntutan dari orang tua untuk mendapatkan IP yang bagus.

b) Menganggap bahwa Indeks Prestasi merupakan hal yang sangat penting.

c) Tidak mempunyai waktu yang cukup untuk menyelesaikan tugas tanpa melakukan kecurangan.

\subsection{Penelitian Relevan}

Penelitian yang dilakukan Pamungkas (2018). Hasil penelitian ini menyatakan bahwa pressure, dan opportunity secara parsial berpengaruh positif signifikan terhadap perilaku kecurangan akademik. Namun rationalization menunjukan berpengaruh negatif signifikan terhadap perilaku kecurangan akademik pada mahasiswa Program Studi Akuntansi Fakultas Ekonomi Universitas Islam Indonesia. 
Penelitian yang dilakukan Apriani dkk (2017). Hasil penelitian ini menyatakan bahwa pressure, dan rationalization secara parsial berpengaruh signifikan terhadap perilaku kecurangan akademik pada mahasiswa akuntansi program S1 Universitas Pendidikan Ganesha. Namun opportunity secara parsial tidak berpengaruh signifikan terhadap perilaku kecurangan akademik pada mahasiswa akuntansi program S1 Universitas Pendidikan Ganesha. Penelitian ini juga menunjukan bahwa secara simultan ketiga variabel independen berpengaruh signifikan terhadap perilaku kecurangan akademik pada mahasiswa akuntansi program S1 Universitas Pendidikan Ganesha.

Penelitian yang dilakukan Prawira dan Irianto (2014). Penelitian ini menggunakan metode penelitian kombinasi dengan model concurrent triangulation yaitu dengan menggabungkan antara metode kuantitatif dan kualitatif secara bersama-sama, baik dalam pengumpulan dan analisis data. Sampel penelitian sebesar 120 mahasiswa serta 5 informan yang merupakan mahasiswa S1 jurusan akuntansi angkatan 2011 yang aktif pada semester genap 2014/2015 di Universitas Brawijaya, Universitas Negeri Malang, dan Universitas Islam Negeri Maulana Malik Ibrahim Malang. Hasil dari penelitian ini memperoleh bukti empiris bahwa perilaku kecurangan akademik mahasiswa dipengaruhi oleh dimensi fraud diamond. Penelitian ini juga menjelaskan tentang mengapa dan bagaimana mahasiswa melakukan perilaku kecurangan akademik sehingga dapat menjadi masukan kepada lembaga terkait untuk meminimalkan perilaku kecurangan akademik.

Penelitian yang dilakukan Oktaviani (2018). Pengambilan sampel dalam penelitian ini menggunakan convenience sampling dan didapatkan 93 responden. Data yang telah terkumpul dianalisis dengan regresi linier berganda dengan bantuan SPSS V. 20. Hasil penelitian menunjukkan bahwa variabel rasionalisasi, kemampuan, keserakahan, dan pengungkapan berpengaruh terhadap kecurangan akademik mahasiswa, sedangkan variabel tekanan, kesempatan, dan kebutuhan tidak berpengaruh terhadap kecurangan akademik mahasiswa.

Kesimpulannya adalah Perbedaan penelitian ini dengan penelitian terdahulu adalah tempat penelitiannya. Penelitian ini dilakukan pada mahasiswa Fakultas Ekonomi Program Studi Pendidikan Akuntansi Universitas Negeri Medan. Berdasarkan hasil penelitian terdahulu dapat disimpulkan ada yang variabel nya berpengaruh signifikan ada juga yang tidak berpengaruh secara signifikan.

\subsection{Kerangka Berpikir}

Beratnya tugas yang diberikan baik dari sisi jumlah yang terlalu banyak maupun tingkat kesukaran soal yang tinggi dapat membebani mahasiswa dan mendesak mahasiswa mencari cara-cara yang cenderung instan. Waktu belajar yang tidak cukup dapat menghambat mahasiswa dalam memahami materi pelajaran maupun kecepatan dan ketepatan dalam pengumpulan tugas yang diberikan. Hal ini dapat mendorong mahasiswa untuk melakukan tindakan kecurangan akademik baik saat ulangan maupun mengerjakan tugas. Dari pengaruh tekanan, peluang dan rasionalisasi dapat dikatakan apabila variabel pressure (tekanan), opportunity (peluang), serta rationalization rasionalisasi) juga bisa saja berpengaruh terhadap kecurangan akademik, karena sejalan dengan teori Fraud Triangle bahwa segitiga kecurangan adalah pressure, opportunity, dan rationalization.

Dengan demikian dapat diasumsikan bahwa pressure, opportunity, dan rationalization merupakan komponen dalam perilaku kecurangan akademik yang dilakukan oleh mahasiswa. Dari penjelasan diatas maka dapat dirumuskan kerangka berpikir sebagai berikut: 
Pengaruh Pressure Terhadap Perilaku Kecuranganak Ademik Pada Mahasiswa Fakultas Ekonomi Programstudi

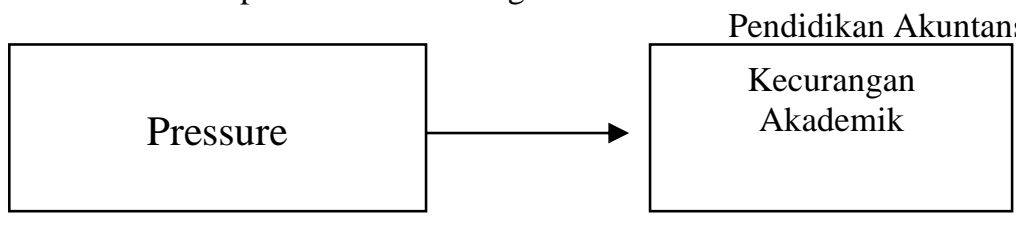

Gambar 2.1 : Kerangka Berpikir

\subsection{Hipotesis}

1. Ada pengaruh pressure (tekanan) terhadap perilaku kecurangan akademik pada mahasiswa Fakultas Ekonomi Program Studi Pendidikan Akuntansi Universitas Negeri Medan.

\section{Lokasi dan Waktu Penelitian}

Penelitian ini dilakukan di fakultas ekonomi program studi pendidikan akuntansi Universitas Negeri Medan. Penelitian dilaksanakan pada semester 2, semester 4, semester 6, dan semester 8 Tahun Pembelajaran 2020/2021 pada angkatan 2016, 2017, 2018, 2019.

3.2 Populasi dan Sampel

\subsubsection{Populasi dan Sampel}

Menurut Arikunto (2010:130) bahwa "populasi adalah keseluruhan subyek penelitian". Populasi dalam penelitian ini adalah mahasiswa fakultas ekonomi program studi pendidikan akuntansi angkatan 2016, 2017, dan 2018 dan 2019 di Universitas Negeri Medan dengan perincian sebanyak 372 mahasiswa

Menurut Arikunto (2010:109) Sampel adalah sebagian dari populasi yang dipandang mewakili populasi untuk dijadikan sebagai sumber data atau informasi dalam suatu penelitian.

Teknik pengambilan sampel yang digunakan dalampenelitian ini adalah Purposive Sampling dengan menggunakan rumus slovin. Penelitian menggunakan teknik pengambilan sampel menggunakan rumus slovin, yakni :

$$
n=\frac{\mathrm{N}}{\mathrm{N} \cdot \mathrm{e}^{2}+1}
$$

\footnotetext{
Keterangan:

$\mathrm{n}=$ jumlah elemen / anggota sampel

$\mathrm{N}=$ jumlah elemen / anggota populasi $\mathrm{e}=$ batas
}

toleransi kesalahan

$$
\mathrm{n}=372\left(\frac{372}{0.05)^{2}+1}=193\right.
$$

Sampel dan responden dalam penelitian ini adalah mahasiswa fakultas ekonomi program studi pendidikan akuntansi Universitas Negeri Medan sebanyak 193 orang yang berasal dari angkatan 2016, 2017, 2018, dan 2019. Jumlah mahasiswa pendidikan akuntansi adalah 372 orang berdasarkan data yang didapat dari puskom Universitas Negeri Medan.

Tabel 3. 2 : Sampel Penelitian

\begin{tabular}{|c|c|c|c|}
\hline No. & Angkatan & Populasi & Ukuran Sampel \\
\hline 1. & 2016 & 77 & $\frac{77}{372} \times 193=39,94$ (dibulatkan 40) \\
\hline
\end{tabular}




\begin{tabular}{|c|c|c|c|}
\hline 2. & 2017 & 97 & $\frac{97}{372} \times 193=50,32$ (dibulatkan 50) \\
\hline 3. & 2018 & 126 & $\frac{126}{372} \times 193=65,37$ (dibulatkan 65) \\
\hline 4. & 2019 & 72 & $\frac{72}{372} \times 193=37,35$ (dibulatkan 38) \\
\hline \multicolumn{2}{|c|}{ Jumlah Sampel } & 193 \\
\hline
\end{tabular}

\section{Variabel Penelitian dan Definisi Operasional}

\subsection{Variabel Penelitian}

Menurut Sugiyono (2010:81) menyatakan bahwa "variabel penelitian adalah suatu atribut, sifat, nilai dari orang, objek, atau kegiatan yang mempunyai variasi tertentu yang ditetapkan oleh peneliti untuk dipelajari dan kemudian ditarik kesimpulannya".

Variabel bebas (X) dalam penelitian ini adalah :

1. Pressure / Tekanan (X1)

2. Perilaku Kecurangan Akademik (Y)

Tabel 3. 3 : Defenisi Operasional

\begin{tabular}{|c|c|c|c|}
\hline Variabel & Defenisi Operasional & Indikator & $\begin{array}{c}\text { Skala } \\
\text { Pengukuran }\end{array}$ \\
\hline Pressure (X) & $\begin{array}{l}\text { Pressure } \\
\text { adalah dekanan) } \\
\text { motivasi seseorang untuk } \\
\text { melakukan kecurangan, } \\
\text { misalnya karena tekanan } \\
\text { karena faktor keuangan, } \\
\text { kebiasaan buruk yang } \\
\text { dimiliki seseorang, faktor } \\
\text { eksternal dan lain-lain. } \\
\text { Tekanan-tekanan } \\
\text { terbesar yang dirasakan oleh } \\
\text { mahasiswa antara lain adalah } \\
\text { keharusan atau pemaksaan } \\
\text { untuk lulus. }\end{array}$ & $\begin{array}{l}\text { a) Kurangnya } \\
\text { pemahaman terhadap } \\
\text { materi perkuliahan } \\
\text { b) Soal } \\
\text { yang sulit. ujian } \\
\text { c) Tuntutan dari } \\
\text { orang tua untuk } \\
\text { mendapatkan IP yang } \\
\text { bagus. Menganggap } \\
\text { d) Indeks Prestasi } \\
\text { bahwa sangat } \\
\text { merupakan hal yang sang } \\
\text { penting. } \\
\text { e) Tidak } \\
\text { mempunyai waktu yang } \\
\text { cukup untuk } \\
\text { menyelesaikan tugas tanpa } \\
\text { melakukan kecurangan. }\end{array}$ & Ordinal \\
\hline
\end{tabular}

\section{Hasil Analisis Dan Pembahasan}

Hasil pengujian hipotesis pertama diketahui bahwa pressure dapat berpengaruh secara signifikan terhadap perilaku kecurangan akademik dilihat dengan nilai koefisien sebesar 0,142 dengan tingkat signifikansinya $0,040<0,05$ hasil ini membuktikan bahwa faktor pressure mempunyai pengaruh positif terhadap kecurangan akademik pada mahasiswa. Akibatnya semakin tinggi pressure (tekanan) yang dirasakan mahasiswa maka akan semakin besar kemungkinan dalam memilih jalan keluar yaitu dengan melakukan kecurangan akademik. 
Hasil penelitian ini konsisten dengan penelitian positif Arifah, Setiyani, dan Arief (2018), Munirah dan Nurkhin (2018). Hasil dari penelitian-penelitian tersebut menjelaskan bahwa tekanan memberikan pengaruh yang signifikan terhadap terjadinya kecurangan akademik. Namun, dalam penelitian Primasari, Suhendro, dan Wahyuningsih (2017) tidak sejalan dengan penelitian ini. Tekanan tidak berpengaruh terhadap kecurangan akademik, menunjukkan bahwa tekanan bukan merupakan salah satu faktor utama yang menjadi pertimbangan dalam terjadinya perbuatan kecurangan akademik.

Kecurangan umumnya dilakukan demi kelancaran studi dan mendapatkan nilai/IP yang baik. Tekanan untuk mendapatkan nilai baik masih merupakan faktor tekanan yang paling dominan yang sering dirasakan oleh mahasiswa baik tekanan dari pihak internal (diri sendiri) maupun pihak eksternal (lingkungan) seperti orang tua dan pihak pemberi beasiswa sehingga menyebabkan seseorang terpaksa melakukan suatu tindakan. Tindakan yang didasari oleh keterpaksaan biasanya tidak memperhatikan baik buruknya suatu tindakan kecurangan tersebut.

Hasil penelitian ini sejalan dengan hasil penelitian yang dilakukan Murdiansyah, Sudarma, dan Nurkholis (2017), Munirah, dan Nurkhin (2018), dan Arifah, Setiyani, dan Arief (2018) dengan menemukan hasil bahwa peluang berpengaruh terhadap academic fraud. Namun ada penelitian yang tidak sejalan dengan hasil penelitian ini yang dilakukan oleh Apriani, Sujana, dan Sulindawati (2017), Zamzam, Mahdi, dan Ansar (2017) dengan menemukan hasil bahwa peluang tidak berpengaruh terhadap academic fraud.

Peluang ada ketika lemahnya suatu sistem seperti kurangnya kontrol yang ketat dan penerapan sanksi yang tidak tegas. Mahasiswa akan melakukan kecurangan ketika mereka tertekan dan dalam keadaan seperti pengawas ujian lalai menjalankan tugasnya yakni mengawasi dengan tidak ketat serta pengawas ujian yang tidak mengambil tindakan tegas kepada mahasiswa yang melakukan kecurangan akademik dapat mempermudah mereka melakukan kecurangan akademik. Hasil pengujian hipotesis ketiga diketahui bahwa rationalization dapat berpengaruh secara signifikan terhadap perilaku kecurangan akademik. Dimana hasil regresi menunjukkan bahwa variabel rasionalisasi memiliki nilai signifikansi di bawah 0,05 yaitu sebesar 0,042. Hasil ini membuktikan bahwa rationalization mempunyai pengaruh positif terhadap terhadap perilaku kecurangan akademik. Akibatnya, semakin besar adanya rationalization yang dimiliki setiap mahasiswa maka semakin besar pula perilaku kecurangan akademik yang dilakukannya selama menjalani kegiatan akademik.

Hasil penelitian ini konsisten dengan penelitian yang dilakukan oleh Munirah dan Nurkhin (2018) yang menunjukkan rationalization berpengaruh positif terhadap academic fraud, dimana dalam penelitian tersebut menyatakan bahwa apabila tingkat rasionalisasi yang dimiliki mahasiswa tinggi, maka akan semakin tinggi juga dalam melakukan kecurangan akademik. Namun berbeda dengan penelitian yang dilakukan oleh Zamzam, Mahdi, dan Ansar (*2017), dan Zaini, Carolina dan Setiawan (2015) menemukan hasil bahwa rasionalisasi berpengaruh negatif terhadap academic fraud.

\section{Kesimpulan}

Berdasarkan hasil penelitian Berdasarkan hasil analisis dan pembahasan, maka kesimpulan yang dapat diambil adalah berikut ini :

1. Pressure (tekanan) terdapat pengaruh positif terhadap perilaku kecurangan akademik pada mahasiswa program studi pendidikan akuntansi fakultas ekonomi Universitas Negeri Medan. Hasil ini menunjukkan bahwa variabel pressure (tekanan) merupakan faktor utama yang menyebabkan seseorang melakukan kecurangan akademik. Semakin besar tekanan, maka semakin besar perilaku kecurangan akademik. Dimana berdasarkan uji secara parsial (Uji t) pressure (tekanan) berpengaruh positif terhadap perilaku kecurangan akademik pada mahasiswa program studi pendidikan akuntansi fakultas ekonomi Universitas Negeri Medan.

Penelitian ini memiliki keterbatasan-keterbatasan yang dapat dijadikan bahan pertimbangan bagi peneliti berikutnya agar memperoleh hasil yang lebih baik. Keterbatasan-keterbatasan tersebut antara lain:

1. Sampel dalam penelitian ini hanya terbatas pada program studi pendidikan akuntansi fakultas ekonomi Universitas Negeri Medan sebanyak 193 orang, akan lebih baik jika sampel yang 
diambil melibatkan responden lebih banyak di seluruh Universitas Negeri di Medan, sehingga hasil penelitian dapat digeneralisasikan dalam lingkup yang lebih luas.

2. Penelitian ini hanya meneliti pengaruh pressure, opportunity, dan rationalization terhadap perilaku kecurangan akademik. Masih ada faktor lain yang dapat memengaruhi kecurangan akademik.

3. Metode pengumpulan data menggunakan kuesioner, sehingga sangat mungkin datanya bersifat subyektif, akan lebih baik bila ditambahkan metode wawancara sehingga hasil penelitian yang diperoleh lebih lengkap dan lebih luas.

\section{Referensi:}

Albrecht, W. Steve, Chad O Albrecht, Conan C Albrecht, and Mark F Zimbelman. (2012). Fraud Examination. 4th ed. Mason, OH: South-Western Cengage Learning.

Ansyar. (2017). Hakikat, Fondasi, Desain \& Pengembangan. Jakarta : Kencana Media Group.

Apriani, Sujana dan Sulindawati. (2017). Pengaruh Pressure, Opportunity, Dan Rationalization Terhadap Perilaku Kecurangan Akademik (Studi Empiris: Mahasiswa Akuntansi Program S1 Universitas Pendidikan Ganesha).

Arifah, Wakhidatul., Rediana Setiyani, dan Sandy Arief. (2018). "Pengaruh Prokrastinasi, Tekanan Akademik, Religiusitas, Locus of Control Terhadap Perilaku Ketidakjujuran Akademik Mahasiswa Pendidikan Akuntansi UNNES”. Economic Education Analysis Journal

Arikunto. (2010). Prosedur Penelitian Suatu Pendekatan Praktik. Jakarta : Rineka Cipta

Fitriana, Annisa., dan Zaki Baridwan. (2012). "Perilaku Kecurangan Akademik Mahasiswa Akuntansi: Dimensi Fraud Triangle”. Jurnal Akuntansi Multiparadigma. Vol.3, No.2

Ghozali. (2013). "Aplikasi Analisis Multivariate Dengan Program IBM SPSS 21 Update PLS Regresi”.

Irianto dan Novianti. 2018. Dealing With Fraud. Malang: UB Press

King. Guyette,Jr. Dan Piotrowski (2009). Online Exams and Cheating: An Empirical Analysis of Business Students' Views. The Journal Of Educators Online.

Kompas.com (2016). Menristek Dikti: Saat Ini Indonesia Negara Darurat Korupsi. https://kupang.kompas.com/read/2016/10/19/13594381/menristek.dikti.saa t.ini.indonesia.negara.darurat.korupsi

Martono, Nanang. 2016. Metodologi Penelitian Kuantitatif. Jakarta: Raja Grafindo 
Mufakkir, Fathin dan Listiadi. (2016). "Pengaruh Faktor yang terdapat dalam Dimensi Fraud Triangle terhadap Perilaku Kecurangan Akademik. Jurnal Pendidikan Akuntansi. Vol 1 No 1, h. 1-9.

Munirah, Anisatul., dan Ahmad Nurkhin. (2018). "Pengaruh Faktor-Faktor Fraud Diamond Dan Gone Theory Terhadap Kecurangan Akademik". Economic Education Analysis Journal.

Murdiansyah, Isnan., Made Sudarma, dan Nurkholis. (2017). "Pengaruh Dimensi Fraud Diamond Terhadap Perilaku Kecurangan Akademik (Studi Empiris Pada Mahasiswa Magister Akuntansi Universitas Brawijaya)”. Jurnal Akuntansi Aktual. Vol. 4, No. 2

Oktaviani (2018). Analisis Faktor-Faktor Yang Mempengaruhi Perilaku Kecurangan Akademik. (Studi Kasus Pada Mahasiswa Akuntansi Angkatan 2014-2016 Fakultas Ekonomi Dan Bisnis Universitas Muhammadiyah Surakarta)

Pamungkas (2018). Pengaruh Pressure, Opportunity, dan Rationalization Terhadap Perilaku Kecurangan Akademik" yang dilakukan pada mahasiswa Program Studi Akuntansi Fakultas Ekonomi Universitas Islam Indonesia.

Prawira dan Irianto (2014). Analisis Pengaruh Dimensi Fraud Dimond Terhadap Perilaku Kecurangan Akademik Mahasiswa. (Studi Kasus pada Mahasiswa S1 Jurusan Akuntansi Perguruan Tinggi Negeri Kota Malang)

Primasari, Dyah Noviana., Suhendro, dan Endang Masitoh Wahyuningsih. (2017). "Perilaku Kecurangan Akademik Mahasiswa Akuntansi Dengan Menggunakan Dimensi Fraud Diamond”. Jurnal Akuntansu dan Sistem Teknologi Informasi. Vol:13 